\title{
ANALISIS MOTIVASI BELAJAR INTERNAL SISWA PROGRAM AKSELERASI KELAS VIII SMP NEGERI 6 AMBON
}

\author{
Silvia Manuhutu \\ Prodi Pendidikan Ekonomi FKIP-UNPATTI \\ Silvia Manuhutu@yahoo.com
}

\begin{abstract}
Abstrak
Penelitian ini dilatarbelakangi oleh pentingnya motivasi belajar internal pada diri siswa. Tidak terlepas juga dengan siswa pada kelas akselerasi. Walaupun memiliki kemampuan intelektual di atas rata-rata, bukan berarti mereka tidak memiliki motivasi belajar dari diri mereka sendiri. Untuk itu Tujuan penelitian ini dilakukan guna mengetahui motivasi belajar internal siswa pada program akselerasi siswa kelas VIII SMP Negeri 6 Ambon.

Penelitian ini merupakan penelitian deskriptif yang bertujuan untuk memberikan gambaran tentang motivasi internal siswa pada program akselerasi di SMP Negeri 6 Ambon. Teknik pengumpulan data yang digunakan adalah kuesioner yang dibagikan kepada responden yakni siswa akslerasi kelas VIII berjumlah 28 orang. Untuk memperkuat data kuesioner, peneliti juga menggunakan pedoman observasi untuk melihat aktivitas yang ditimbulkan sebagai bagian dari motivasi internal yang ditunjukkan siswa.

Hasil penelitian menunjukan bahwa motivasi belajar internal siswa pada program akselerasi siswa kelas VIII SMP Negeri 6 Ambon termasuk dalam kategori cukup baik. Hal ini terlihat dari prosentase masing-masing indicator motivas internal siswa. Indikator kuatnya kemauan untuk berbuat mendapat prosentase 47,62\%. Indikator Jumlah waktu yang disediakan untuk belajar mendapat prosentase 38,09. Indikator kerelaan meninggalkan kewajiban atau tugas yang lain mendapat prosentase $61,91 \%$. Serta indicator ketekunan dalam mengerjakan tugas mendapat prosentase $61,91 \%$.
\end{abstract}

Kata Kunci: Motivasi Belajar Internal.

\section{PENDAHULUAN}

Dalam proses pendidikan di sekolah, kegiatan belajar merupakan kegiatan yang paling utama. Hal ini menunjukan bahwa berhasil tidaknya pencapaian tujuan pendidikan tergantung kepada bagaimana proses belajar yang dialami oleh siswa sebagai anak didik. Pada hakikatnya, ditinjau dari aspek kemampuan dan kecerdasan, siswa dapat dikelompokkan ke dalam 3 strata, yaitu yang memiliki kemampuan dan kecerdasan dibawah rata-rata, rata-rata dan di atas rata-rata kelas. Siswa yang berada di bawah rata-rata memiliki kecepatan belajar dibawah siswa pada umumnya, dan siswa yang berada pada kemampuan rata-rata memiliki kecepatan belajar 
siswa dibawah rata-rata pada umumnya sedangkan siswa yang berada di atas rata-rata memiliki kecepatan belajar di atas siswa pada umumnya.

Dalam komunitas kelas, sadar atau tidak disadari selalu didapati beberapa siswa yang memiliki kemampuan belajar di atas rata-rata kelas. H. Martinis Yamin (2010) mengatakan bahwa, dalam penelitian jumlah mereka sekitar $10 \%$ dari keseluruhan anggota kelas. Mereka mempunyai kemampuan lebih yang tidak bisa disamakan dengan siswa lainnya.

Bagi siswa yang memiliki kemampuan dan kecerdasan ratarata, selama ini diberikan pelayanan pendidikan dengan mengacu pada kurikulum pada umumnya atau kurikulum standar untuk semua sekolah. Sementara itu bagi siswa yang memiliki kemampuan di bawah rata-rata karena memiliki kemampuan di bawah siswa-siswa lainnya, diberikan pelayanan pendidikan berupa remidial (Remidial Teaching) sehingga untuk menyelesaikan materi kurikulum membutuhkan waktu lebih panjang dari pada siswa-siswi lainnya, sedangkan bagi siswa yang memiliki kemampuan di atas rata-rata kini juga telah mendapat fasilitas pelayanan pendidikan berupa program percepatan belajar (akselerasi), siswa yang memiliki kecepatan dan kecerdasan di atas ratarata sebenarnya mempunyai kebutuhan yang berbeda dari siswa lainnya, sehingga mereka dapat berprestasi sesuai dengan bakat dan potensinya.

Dalam kelas reguler yang tidak memperoleh penanganan secara proporsional mereka dapat mengganggu teman lainnya. Ketika siswa biasanya menyelesaikan tugas kelas selama misalnya 50 menit, mereka yang berkemampuan di atas rata-rata biasanya akan menyelesaikan tugasnya misalnya 35 menit, kelebihan waktu ini akan berakibat kontrak produktif yang apabila berakumulasi akan menyebabkan gangguan kelas yang serius bagi individu siswa sendiri maupun kelas. Itulah sebabnya para pakar pendidikan menyarankan ada perlakuan khusus bagi siswa unggul (gifted) dengan penyelenggaraan pendidikan tersendiri secara terpisah atau melakukan kegiatan pengayaan (enrichment) materi pada kelas reguler.

Program percepatan belajar 
(akselerasi) merupakan pelayanan pendidikan yang berdiferensiasi yaitu memberikan pelayanan pendidikan yang disesuaikan dengan kemampuan dan kecerdasan siswa dengan menggunakan kurikulum yang berdiversifikasi, yaitu kurikulum standart yang diimprovisasi alokasi waktunya sesuai dengan kecepatan belajar siswa. Pelayanan pendidikan yang berdiferensiasi dengan menggunakan kurikulum yang berdiversifikasi dapat diimplementasi melalui penyelenggaraan sistem percepatan belajar (akselerasi). Dengan sistem percepatan belajar (akselerasi), siswa yang memiliki kemampuan dan kecerdasan luar biasa diberi peluang untuk menyelesaikan studi di SD kurang dari 6 Tahun (misalnya 5 tahun), di SMP dan SMA masing-masing kurang dari 3 tahun (misalnya 2 tahun), dengan menyelesaikan semua target kurikulum tanpa meloncat kelas.

Program akselerasi pada prinsipnya menjadikan kurikulum standar yang biasanya di tempuh siswa dalam 3 tahun menjadi hanya 2 tahun. Pada tahun pertama, peserta didik program akselerasi akan mempelajari materi kelas 1 dan ditambah setengah materi kelas 2 dan ditahun ke-2, mereka akan mempelajari materi kelas 2 yang tersisa (tinggal 1 semester) di tambah dengan seluruh materi kelas 3 .

Secara teori Meier dan Rose (Aghusthin Amarmolo, 2010) mengungkapkan prinsip-prinsip accelerated learning (AL), yaitu :

1. Belajar melibatkan seluruh pikiran dan tubuh.

Belajar tidak hanya mengunakan otak, tetapi juga melibatkan seluruh tubuh atau pikiran dengan segala emosi, indra dan syarafnya.

2. Belajar adalah berkreasi bukan mengkonsumsi.

Pengetahuan bukanlah sesuatu yang diserap oleh pembelajar, melainkan sesuatu yang diciptakan pembelajar.

3. Kerjasama membantu proses belajar.

Semua usaha belajar yang baik mempunyai landasan sosial. Kita biasanya belajar dengan beriteraksi dengan teman-teman dari pada yang kita pelajari dengan cara lain manapun. Persaingan diantara pembelajar memperlambat pembelajaran. Kerjasama diantara mereka mempercepatnya. Suatu komunitas belajar selalu lebih baik 
hasilnya dari pada beberapa individu yang belajar sendirisendiri.

\section{Pembelajaran berlangsung pada} berbagai tingkatan secara simultan.

Belajar bukan hanya menyerap satu hal kecil pada satu waktu secara linear, melainkan menyerap banyak hal sekaligus pembelajaran yang baik melibatkan orang pada banyak tingkatan secara simultan (sadar dan bawah sadar, mental dan fisik) dan memanfaatkan seluruh saraf reseptor, indera, jalan dalam sistem otak / tubuh seseorang.

5. Belajar berasal dari mengerjakan pekerjaan itu sendiri (dengan umpan balik).

Belajar paling baik adalah dalam konteks.Pengalaman yang nyata dan konkret dapat menjadi guru yang jauh lebih baik dari pada sesuatu yang hipotesis dan abstrak, asalkan didalamnya tersedia peluang untuk terjun langsung secara total, mendapatkan umpan balik, merenung dan menerjunkan diri kembali.

6. Emosi positif sangat membantu pembelajaran.
Perasaan menentukan kualitas dan juga kuantitas belajar sesorang. Perasaan negatif menghalangi belajar, perasaan positif mempercepatnya. Belajar yang penuh tekanan, menyakitkan dan bersuasana muram tidak dapat mengungguli hasil belajar yang menyenangkan, santai dan menarik.

\section{Otak citra menyerap informasi} secara langsung dan otomatis.

Sistem saraf manusia lebih merupakan prosesor citra dari pada prosesor kata. Gambar konkret jauh lebih mudah ditangkap dan disimpan daripada abstrak verbal. Menerjemahkan abstraksi verbal menjadi berbagai jenis gambar konkret akan membuat abstraksi verbal itu bisa lebih cepat dipelajari dan lebih mudah di ingat.

Program percepatan belajar (akselerasi) mulai dicanangkan pada tahun 2000 oleh Menteri Pendidikan Nasional sebagai salah satu program pendidikan nasional untuk anak berbakat intelektual. Sejak program ini dicanangkan tidak sedikit sekolahsekolah di Indonesia yang kemudian membuka program tersebut. Program pendidikan akselerasi merupakan 
bentuk pelayanan yang positif dan memberikan alternatif bagi anak berbakat secara intelektual agar dapat berkesempatan untuk mengembangkan kemampuannya secara optimal.

Namun fenomena yang terjadi tidak semua siswa yang memiliki keberbakatan intelektual termotivasi untuk mengikuti program akselerasi. Hal ini sejalan dengan kenyataan yang terjadi pada SMP Negeri 6 Ambon. Sekolah yang berlokasi di Jln Kakialy adalah salah satu sekolah yang telah menerapkan program akselerasi dari tahun 2008, penerapannya dimulai dari kelas VII biasanya untuk dapat masuk di kelas akselerasi siswa harus melewati tes yang diberikan, namun dari sekian banyaknya siswa yang terdaftar pada SMP Negeri 6 Ambon hanya sebagian kecil siswa yang termotivasi untuk mengikuti program akselerasi dan didalam penyelengaraannya sering terjadi beberapa persoalan diantaranya. siswa akselerasi yang di tengah-tengah pelaksanaan program pembelajarannya harus pindah ke kelas reguler atau mengalami prestasi yang tidak sesuai dengan keberbakatannya hal ini dipengaruhi oleh kurang adanya perasaan senang dalam mengikuti pelajaran, kemauan untuk maju siswa sangat rendah, kecerdasannya mulai menurun serta siswa tersebut belum bisa untuk mandiri. Hal ini sejalan dengan pendapat Coleman (1985:27) anakanak berbakat belum tentu baik dalam segala hal, anak tersebut bisa memperoleh kelas-kelas yang rendah, bisa memiliki persoalan perilaku dan bisa juga memiliki kesenjangan dalam bidang keahlian tertentu.

Dalam proses belajar, motivasi sangat diperlukan, sebab seseorang yang tidak mempunyai motivasi dalam belajar, tidak akan mungkin melaksanakan aktivitas belajar. Motivasi berasal dari kata "motif" yang diartikan sebagai daya upaya yang mendorong seseorang untuk melakukan sesuatu. Menurut Sardiman (2006:73) motif merupakan daya penggerak dari dalam untuk melakukan kegaiatan untuk mencapai tujuan.

Menurut Mulyasa (2003:112) motivasi adalah tenaga pendorong atau penarik yang menyebabkan adanya tingkah laku ke arah suatu tujuan tertentu. Peserta didik akan bersungguh-sungguh karena memiliki motivasi yang tinggi. Seorang siswa 
akan belajar bila ada faktor pendorongnya yang disebut motivasi. Dimyati dan Mudjiono (2002:80) mengutip pendapat Koeswara mengatakan bahwa siswa belajar karena didorong kekuatan mental. Kekuatan mental itu berupa keinginan dan perhatian, kemauan, cita-cita di dalam diri seorang Terkadang ada keinginan yang mengaktifkan, menggerakkan, menyalurkan dan mengarahkan sikap dan perilaku individu dalam belajar.

Jadi dapat disimpulkan bahwa motivasi belajar adalah keseluruhan daya penggerak didalam diri siswa yang menimbulkan kegiatan belajar menjamin kelangsungan dan memberikan arah pada kegiatan belajar sehingga tujuan yang dikehendaki dapat tercapai. Dalam motivasi belajar dorongan merupakan kekuatan mental untuk melakukan kegiatan dalam rangka pemenuhan harapan dan dorongan dalam hal ini adalah pencapaian tujuan.

Motivasi diperlukan dalam menentukan intensitas usaha belajar bagi para siswa. Menurut Djamarah (2002 : 123) ada tiga fungsi motivasi, yakni :

1. Motivasi sebagai pendorong perbuatan. Motivasi berfungsi sebagai pendorong untuk mempengaruhi sikap apa yang seharusnya anak didik ambil dalam rangka belajar.

2. Motivasi sebagai penggerak perbuatan. Dorongan psikologis melahirkan sikap terhadap anak didik itu merupakan suatu kekuatan yang tak terbendung,yang kemudian terjelma dalam bentuk gerakan psikofisik.

3. Motivasi sebagai pengarah perbuatan. Anak didik yang mempunyai motivasi dapat menyeleksi mana perbuatan yang harus dilakukan dan perbuatan yang perlu diabaikan.

Motivasi dalam proses pembelajaran berasal dari dalam diri siswa dan juga berasal dari luar dirinya. Motivasi yang berasal dari diri siswa disebut motivasi intrinsik dan yang berasal dari luar diri siswa disebut motivasi ekstrinsik (Dimyati dan Mudjiono, 2002:90). Dalam pembahasan penelitian ini, penulis hanya menyampaikan teori motivasi intrinsic sesuai dengan muatan penelitian ini.

Motivasi Intrinsik adalah motivasi yang timbul dari dalam diri 
pribadi individu itu sendiri tanpa adanya pengaruh dari luar individu. Motivasi yang bekerja dalam diri individu mempunyai kekuatan yang berbeda-beda. Ada motif yang begitu kuat sehingga menguasai motif motif lainnya. Motif yang paling kuat adalah motif yang menjadi sebab utama tingakh laku individu pada saat tertentu.

Menurut Handoko (1992: 59), untuk mengetahui kekuatan motivasi belajar siswa, dapat dilihat dari beberapa indicator sebagai berikut :

1) Kuatnya kemauan untuk berbuat

2) Jumlah waktu yang disediakan untuk belajar

3) Kerelaan meninggalkan kewajiban atau tugas yang lain

4) Ketekunan dalam mengerjakan tugas.

Sedangkan menurut Sardiman

(2001: 81) indikator motivasi

belajar adalah sebagai berikut :

1) Tekun menghadapi tugas.

2) Ulet menghadapi kesulitan (tidak lekas putus asa)

3) Menunjukan minat terhadap bermacam-macam masalah orang dewasa.

4) Lebih senag bekerja mandiri

5) Cepat bosan pada tugas rutin
6) Dapat mempertahankan pendapatnya.

Apabila seseorang memiliki ciri di atas berarti seseorang itu memiliki motivasi yang tinggi.

\section{METODE PENELITIAN}

Penelitian ini menggunakan tipe penelitian deskriptif yaitu penelitian yang bertujuan memberikan gambaran secara sistematis tentang keadaan atau situasi (kejadian) mengenai suatu objek penelitian pada daerah tertentu (Husein Umar, 2008:75). Peneliti menggunakan tipe penelitian ini untuk dapat menggambarkan keadaan yang terjadi dalam kelas VIII Akselerasi SMP Negeri 6 Ambon. Subjek Penelitian adalah siswa kelas VIII Akselerasi berjumlah 28 orang.

Data utama penelitian dikumpulkan menggunakan kuesioner. Kuesioner diberikan kepada para siswa yang mengikuti program akselerasi untuk mendapatkan data tentang motivasi internal siswa. Selanjutnya peneliti menggunakan wawancara untuk melengkapi data kuesioner.Hasil pengumpulan data kemudian dianalisis secar diskriptif kuantitatif mengacu kepada criteria pengambilan 
keputusan terhadap motivasi belajar internal siswa pada program akselerasi seperti diuraikan pada tabel berikut.

\section{Tabel 1}

Kriteria Pengukuran Motivasi Belajar Internal Siswa Pada Program Akselerasi

\begin{tabular}{|l|l|}
\hline Tingkat Pencapaian & Kualifikasi \\
\hline $81 \%-100 \%$ & Sangat Baik \\
\hline $61 \%-80 \%$ & Baik \\
\hline $41 \%-60 \%$ & Cukup Baik \\
\hline $21 \%-40 \%$ & Kurang Baik \\
\hline $0 \%-20 \%$ & Sangat Tidak Baik \\
\hline
\end{tabular}

Sumber : Sugiyono (2009: 232)

PEMBAHASAN HASIL PENELITIAN
Dalam penelitian ini, motivasi internal siswa diuraikan berdasarkan indicator kuatnya kemauan untuk berbuat, jumlah waktu yang disediakan untuk belajar, kerelaan meninggalkan kewajiban atau tugas yang lain serta ketekunan dalam mengerjakan tugas.

Setiap indicator memiliki tiga pernyataan terkait motivasi internal siswa. Prosentase untuk masingmasing indicator sebesar $100 \%$. Adapun hasil rekapitulasi prosentase kuiesioner dapat dilihat pada table di bawah ini.

Tabel 2

Rekapitulasi prosentase kuisioner

\begin{tabular}{|c|l|c|c|}
\hline No & \multicolumn{1}{|c|}{ Indikator } & Prosentase (\%) & Kategori \\
\hline 1 & Kuatnya kemauan untuk berbuat & 47,62 & Cukup Baik \\
\hline 2 & $\begin{array}{l}\text { Jumlah waktu yang disediakan untuk } \\
\text { belajar }\end{array}$ & 38,09 & Kurang Baik \\
\hline 3 & $\begin{array}{l}\text { Kerelaan meninggakan kewajiban atau } \\
\text { ugas yang lain }\end{array}$ & 61,91 & Baik \\
\hline 4 & Ketekunan dalam mengerjakan tugas & 61,91 & \\
\hline
\end{tabular}

Sumber : Hasil Olah Data.

Dari table 2 di atas, terlihat

bahwa indicator ke-3 dan ke-4 memiliki prosentase nilai yang sama yakni $61,91 \%$ dan termasuk dalam kaegori baik. Sedangkan untuk indicator 1 memiliki prosentase 47,62\% masuk kategori cukup baik dan indicator 2 memiliki prosentase 38,09\% dengan kategori kurang baik.

1. Kuatnya Kemauan Untuk
Berbuat

Seseorang yang belajar dengan semangat yang tinggi maka akan menunjukan hasil yang baik. bagaimana pendapat Sadirman (2001:85), yang menyatakan bahwa intensitas belajar siswa akan sangat menentukan tingkat pencapaian tujuan belajarnya yakni meningkatkan prestasinya.

Menurut Sardiman (Yunike L Makaweru 2013:17) fungsi belajar ada 
tiga, salah satunya mendorong manusia untuk berbuat dalam hal ini sebagai penggerak atau motor yang melepaskan energi. Motivasi dalam hal ini merupakan motor penggerak dari setiap kegiatan yang akan dikerjakan.

Berdasarkan uraian data per indikator dari variabel motivasi belajar internal dapat diketahui bahwa siswa memiliki keinginan yang cukup dalam belajar, dengan presentase ratarata sebesar 47,62\%. Hal ini dapat dilihat pada saat proses belajar mengajar ada siswa yang tidak memperhatikan guru didepan yang mengakibatkan siswa pun bertanya kepada guru soal materi yang di sampaikan karena tidak memahami, juga dapat dilihat pada jawaban siswa dari pernyataan-pernyataan pada indikator kuatnya kemauan untuk berbuat.

\section{Jumlah waktu yang disediakan untuk belajar

$$
\text { Carroll dalam Syamsudin }
$$

(1983:84) berasumsi bahwa, jika setiap siswa diberi kesempatan belajar dengan waktu yang sesuai dengan yang dibutuhkan oleh masing-masing anak, maka mereka akan mampu mencapai tarap penguasaan yang sama. Oleh karena itu, tingkat penguasaan belajar merupakan fungsi dari proporsi jumlah waktu yang disediakan guru, dengan jumlah waktu yang diperlukan anak untuk belajar. Motivasi belajar, kemampuan memahamai pembelajaran, dan kualitas pembelajaran merupakan faktor-faktor yang ikut berpengaruh terhadap kualitas penguasaan belajar.

Dari tiga pernyataan yang ada pada indikator jumlah waktu yang disediakan untuk belajar, responden kurang baik dalam pemanfaatan waktu. Hal ini dikarenakan terkadang ada siswa yang tidak mengerjakan tugas, dalam hal ini PR (pekerjaan rumah) dan tidak berlatih soal-soal tes yang ada dalam buku referensinya.

\section{Kerelaan} meninggalkan

\section{kewajiban atau tugas yang lain}

Agar mendapatkan hasil belajar yang baik, seorang siswa haruslah mengutamakan belajar dari pada kegiatan lain. Dari hasil olahan data pada indikator kerelaan meninggalkan kewajiban atau tugas lain, siswa memberikan jawaban dengan presentase rata-rata $61,91 \%$, maka dapat dikatakan bahwa indikator kerelaan meninggalkan kewajiban atau tugas lain termasuk dalam kategori "baik". Hal ini dilihat pada waktu istirahat terkadang ada siswa yang lebih memilih tetap dikelas 
untuk membaca ulang materi yang disampaikan oleh guru serta ada yang lebih memilih ke perpustakaan.

\section{Ketekunan dalam mengerjakan tugas}

Ketekunan adalah upaya bersinambung untuk mencapai tujuan tertentu tanpa mudah menyerah hingga meraih keberhasilan (Ranjit Singh Malhi, Enhancing Personal Quality,2005). Hal ini dibuktikan dengan ketekunan dan keseriusan siswa saat menyelesaikan tugas dalam proses belajar mengajar tepat dengan waktu yang telah ditentukan guru dan jika siswa terlambat dalam menyelesaikannya dikenai sanksi karena itu responden pada umumnya selalu memiliki buku cetak untuk dijadikan referensi.

Dengan demikian dapat disimpulkan bahwa motivasi belajar internal siswa cukup baik. Hal ini membuktikan bahwa tidak selamanya siswa yang memiliki kecerdasan diatas rata-rata juga memiliki motivasi belajar internal yang tinggi. Hal ini sejalan dengan pendapat Coleman (1985:27) anak-anak berbakat belum tentu baik dalam segala hal, anak tersebut bias memperoleh kelas- kelas yang rendah, bias memiliki persoalan perilaku, dan bias memiliki kesenjangan dalam bidang keahlian tertentu.

\section{KESEIMPULAN}

Dari hasil penelitian dan pembahasan yang telah dilaksanakan oleh peneliti maka dapat disimpulkan bahwa :

1) Hasil penelitian pada variabel motivasi belajar internal siswa pada program akselerasi siswa kelas VIII SMP Negeri Ambon menunjukan bahwa siswa memilki motivasi belajar internal cukup baik.

2) Analisis motivasi belajar internal siswa kelas VIII program akselerasi SMP Negeri 6 Ambon pada indikator kuatnya kemauan untuk berbuat termasuk dalam kategori "cukup baik" hal ini dilihat dari presentase rata-rata sebenarnya $47,62 \%$. Dengan demikian dapat dikatakan bahwa keinginan siswa untuk berbuat adalam hal ini adalah belajar cukup baik.

3) Untuk indikator jumlah waktu yang disediakan untuk belajar termasuk dalam kategori "kurang baik" dilihat dari presentase ratarata sebesar 38,09\%. Maka dapat dikatakan bahwa responden 
cukup baik dalam membagi waktu.

4) Hasil pengolahan data pada indikator kerelaan meninggalkan kewajiban atau tugas lain dan indikator ketekunan dalam mengerjakan tugas, keduanya termasuk dalam kategori " baik" dapat lihat dari presentase ratarata sebenarnya $61,91 \%$. Jadi dapat dikatakan bahwa siswa mampu mengetahui bahwa belajar adalah kewajiban atau prioritas utamanya dan siswa selalu mengerjakan tugas dengan tekun.

Bertolak dari kesimpulan diatas maka penulis menyarankan :

1) Bagi kepala sekolah agar lebih teliti dan kopemtitif dalam melakukan tes masuk program akselerasi.

2) Para guru dalam proses pembelajaran dapat memotivasi siswa kelas akselerasi dengan cara memberikan arahan-arahan dan nasehat.

3) Pihak sekolah harus bekerja sama dengan para orang tua siswa, dalam hal ini saling bertukar informasi tentang perkembangan siswa lewat pertemuan orang tua murid atau pembagian laporan pendidikan.

4) Untuk siswa agar dapat memotivasi diri dalam belajar dan tidak hanya bergantung pada guru karena motivasi belajar paling baik adalah dari dalam diri sendiri.

\section{DAFTAR PUSTAKA}

Amarmolo.A. 2010. Skripsi. Karya Ilmiah Tidak Dipublikasikan. Universitas Pattimura, Ambon

Coleman. 1985.Shooling The Gifted Meni O Park, Ca: Addi SonWesi Ey

Dimyati. 2005. Belajar dan Pembelajaran.Jakarta: Depdikbud.

Djamarah. 2002. Strategi Belajar Mengajar. Jakarta : RinekaCipta.

Handoko. 1992. Motivasi Daya Pengerak Tingkah Laku. Jakarta: Reneka Cipta

H.Martinis Yamin. 2010. Srategi Pembelajaran Berbasis Kompetensi. Jakarta : Gaung Persada

Husein, Umar. 2008. Metode Penelitian Untuk Sekripsi Dan Bisnis. Jakarta: Rajawali Pers

Mulyasa. 2003. Kurikulum Berbasis Kompetensi. Bandung : Rosdakarya

Rajit Singh Malhi. 2005. Enhancing Personal Quality. 
ISSN: 2442-9449 Vol.3.NNo.1 (2015) 104-115

Sardiman,A.M. 2001. Interaksi dan Motivasi Belajar Mengajar. Jakarta : Grafindo.

Sardirman A. M. 2006. Interaksi dan Motivasi Belajar Mengajar. Jakarta : Grafindo.

Syamsudin. 1983. Psikologi kependidikan. Bandung: rosdakarya.

Yunike 1 makaweru. 2013. Skripsi, karya ilmiah tidak di publikasikan. ambon: universitas pattimura. 